\title{
Het beeld van de adel bij Melis Stoke. De adelspolitiek van de Hol- landse graven in het begin van de veertiende eeuw'
}

\section{J. W. J. BURGERS}

Op zaterdag 1 augustus van het jaar 1299 kwam er een even onverwacht als roemloos einde aan het leven van Wolfert van Borsele, sinds 1297 de machtigste man van het graafschap Holland en Zeeland. De titulaire heerser graaf Jan I, bij zijn opvolging in 1296 pas twaalf jaar oud, stond namelijk onder Wolferts hoede en danste volledig naar diens pijpen. Wolfert gebruikte zijn positie om de alleenheerschappij aan zich te trekken en zich schaamteloos te verrijken, wat leidde tot conflicten met de ingezetenen van het graafschap; dat leidde uiteindelijk tot zijn ondergang. Een gedetailleerd verslag van de gebeurtenissen in de voor Borsele noodlottige dagen lezen we in de Rijmkroniek van Holland, geschreven door de grafelijke klerk Melis Stoke.

Stoke, vanaf 1296 stadsklerk in Dordrecht, maakte eind november 1299 de overstap naar de kanselarij van de nieuwe Hollandse graaf, Jan II van Henegouwen. In die omgeving bleef Stoke tot in 1305 aanwijsbaar ${ }^{2}$. Daar ook schreef hij in de jaren 1301-1302 het eerste vervolg op een al rond 1280 door een anonymus vervaardigde Hollandse Rijmkroniek; in zijn continuatie behandelde Stoke de jaren 1205-1301. Later schreef hij in opdracht van graaf Willem III nog een vervolg, waarin hij verslag deed van de gebeurtenissen uit de periode 1302-1305; die continuatie zal hij in of kort na laatstgenoemde jaar hebben vervaardigd ${ }^{3}$. Stoke was dus de aangewezen persoon om de geschiedenis te schrijven van het graafschap Holland en Zeeland in de cruciale jaren 1296-1304; hij verkeerde in de hoogste kringen, was aanwezig bij veel van de door hem beschreven gebeurtenissen, en doet daarvan over het algemeen getrouw en accuraat verslag 4 . Naar we zullen zien zou deze waarheidslievendheid hem evenwel niet beletten om de feiten enigszins bij te kleuren in een voor zijn broodheren, de Hollands-Henegouwse graven, welgevallige zin.

In Stokes kroniek nu lezen we dat Wolferts protégé Aloud van Yerseke, de baljuw van Zuid-Holland, in conflict was geraakt met de inwoners van Dordrecht over een juridische competentiekwestie; beide partijen wilden zich het recht voorbehouden bepaalde misdadigers te berechten ${ }^{5}$. Wolfert reisde met de jonge graaf naar Dordrecht toe, en eiste op hoge toon dat de Dordtenaren zouden inbinden. Dezen hielden echter

1 Dit is de geannoteerde en enigszins bewerkte tekst van een voordracht, zoals die op 10 mei 1997 werd gehouden tijdens het 44 ste Nederlands-Vlaams Historisch Congres in Leiden. Dr. A. Janse was zo vriendelijk de eerste versie van dit artikel te voorzien van kritisch commentaar.

2 J. W. J. Burgers, 'De loopbaan van de klerk Melis Stoke', Bijdragen en mededelingen betreffende de geschiedenis der Nederlanden, CVIII (1993) 20-27.

3 Op de genese van de Rijmkroniek van Holland zal uitvoerig worden ingegaan in een eerlang te verschijnen studie van auteur dezes.

4 Over de betrouwbaarheid van Stoke als geschiedschrijver zie J. W. J. Burgers, 'Melis Stoke, literator of geschiedschrijver?', Millennium. Tijdschrift voor middeleeuwse studies, XI (1997) 15-33.

5 Rijmkroniek van Melis Stoke, W. G. Brill, ed. (2 din.; Utrecht, 1885; ongewijzigde herdr. in 1 bd. Utrecht, 1983) boek V, verzen 288-899. Zie over deze gebeurtenissen M. S. Pols, 'Graaf Jan I van Holland', 
voet bij stuk, waarop hun werd bevolen dat enkele vooraanstaande burgers als gijzelaars naar Delft zouden gaan. Aan dit bevel gaven zij gehoor, terwijl andere burgers als onderhandelaars Wolfert achterna reisden. Toen Borsele ook in Delft was aangekomen, blies hij opnieuw hoog van de toren, de Dordtenaren uitmakend voor leugenaars, waarmee hij het ongenoegen opwekte van de Delftse schepenen. Vanwege de dreigende sfeer besloten de Dordtse burgers er heimelijk vandoor te gaan. Thuis gekomen sloegen ze het beleg voor het kasteel van Sliedrecht, waar de baljuw Aloud zich had verschanst. Wolfert en de graaf bevonden zich intussen in Den Haag, en daar barstte de bom. Men vernam van de vijandelijkheden bij Dordrecht, en Wolfert trof voorbereidingen om Aloud te hulp te schieten. Dit viel niet goed bij het volk, dat nu op het punt stond in opstand te komen tegen de toch al impopulaire Borsele. Deze werd de grond te heet onder de voeten, en hij trachtte heimelijk, in het holst van de nacht, naar Zeeland te ontkomen; hij nam graaf Jan met zich mee. Toen 's ochtends die verdwijning bekend werd, ontvlamde het volk in woede en zette het de achtervolging in. Wolfert had op zijn vlucht de bruggen achter zich laten vernielen en was in Schiedam scheep gegaan om de Nieuwe Maas over te steken; vanwege de zwakke wind schoot hij echter niet erg op. De achtervolgers sprongen in Vlaardingen in boten en haalden hem al roeiend in. De graaf werd in triomf naar Den Haag gevoerd, Wolfert op een kar naar Delft gereden. Daar werden hij en zijn gevangen medestanders in een stenen huis opgesloten. Het volk liep echter te hoop en eiste uitlevering van de gehate Borsele, waarop de bang geworden bewakers hem naar buiten duwden. Prompt werd de onfortuinlijke edelman door de menigte doodgeslagen, voor de ogen van zijn vrouw.

Bij lezing van dit verslag in de Rijmkroniek valt op dat Stoke Borseles ondergang van harte toejuicht. Ook elders geeft hij herhaaldelijk blijk van zijn afkeer van de Zeeuw $^{6}$. Dat is niet verwonderlijk, want Wolfert was de grootste vijand van Stokes opdrachtgever, graaf Jan II. Deze kreeg dankzij de dood van Borsele vaste voet in Holland, en liet zich door Jan I zelfs aanstellen tot regent van het graafschap; na het overlijden van de jonge graaf op 10 november 1299 volgde hij hem op. Het is voorts duidelijk dat Stoke het volk opvoert als de partij die Borsele ten val brengt. Eerst raakt Wolfert in conflict met de Dordtse burgers, dan met die van Delft, en ten slotte is het het naamloze volk dat tegen hem in opstand komt, hem achtervolgt, gevangen neemt en doodt. Dit bevreemdt wél enigszins, want men zou verwachten dat niet zozeer het gewone volk een reden had om een wrok tegen hem te koesteren, als wel de adel. Wolfens alleenheerschappij en zijn daaruit voortvloeiende persoonlijke verrijking gingen immers ten koste van de politieke en materiële positie van de overige hoge edelen van het graafschap, die hun invloed bij de graaf hadden verloren en met lede ogen moeten hebben toegezien hoe Borsele zichzelf door de graaf liet begiftigen met verschillende rechten en goederen. Stoke meldt dan ook dat Wolfert door zijn standgenoten werd gehaat ${ }^{7}$.

S. Muller Fz., ed., Bijdragen voor de vaderlandsche geschiedenis en oudheidkunde, 3e reeks, X (1899) tweede paginering, 1-55, alsmede de 'Aantekening' door R. F[ruin], Ibidem, 55-60.

6 Stoke, Rijmkroniek, V, 660/1 -72, 1183-1322, VI, 262-287, 872-944.

7 Stoke, Rijmkroniek, VI, 872-944. 
We slaan daarom eens een ander verslag over deze gebeurtenissen op, en wel de kroniek van Willem Jacobszoon, kapelaan van de heer van Brederode, beter bekend als de Procurator, naar zijn latere functie in de abdij van Egmond. De Procurator schreef zijn boek in 1321, maar hij was rond 1300 al tot de jaren des onderscheids gekomen, en dus een contemporain waarnemer van het drama. Ook de Procurator heeft het over de haat van de Hollanders in het algemeen jegens Borsele, vanwege diens wrede en willekeurige optreden, en over een volksoploop tegen hem toen hij met de graaf in Den Haag verbleef. Daarnaast speelt echter in dit verslag de adel een duidelijk actieve rol. De edelen verheffen openlijk hun stem tegen de 'verrader', hoewel dat op dat moment zeer gevaarlijk was, en smeedden een geheim complot om Wolfert ten val te brengen. Deze raakte daarvan echter op de hoogte door de loslippigheid van een van de betrokkenen, waarna hij zijn heimelijke vlucht ondernam. Daarop besloten de edelen 'wonend langs de Maas' eveneens om tegen Wolfens gezag in opstand te komen, en ze namen hem gevangen. Het vervolg van het verhaal is gelijk aan de versie van Stoke: opsluiting in een stenen huis te Delft, de woedende omstanders die dreigen het huis in brand te steken, Wolfert die als een canes rabidus, een dolle hond, naar buiten wordt gestoten en met 'ongeveer duizend steken' wordt gedood. 8. Uit de lezing van de Procurator kunnen we dus opmaken dat inderdaad het volk in opstand kwam tegen Wolfert, maar dat tegelijk ook een aantal edelen tegen Borsele samenzweerde, en mogelijk de volkswoede gebruikte of zelfs mobiliseerde om hun doel, uitschakeling van Borsele, te bereiken.

We hebben nog een bron die ons inlicht over de dood van Borsele, namelijk een oorkonde van 11 mei $1309^{9}$. Op die dag deden Gwijde van Avesnes, bisschop van Utrecht en oom van graaf Willem III, graaf Willem zelf, en Gerard van Voorne in zijn hoedanigheid van burggraaf van Zeeland, te Poelduinen uitspraak ter verzoening van de vete die was voortgekomen uit de moord op Borsele. Deze uitspraak is te plaatsen in het kader van een verzoening tussen de graaf en de Hollandse edelen enerzijds en de Zeeuwse adel onder aanvoering van de Borseles anderzijds, welke partijen sedert 1300 in staat van oorlog waren ${ }^{10}$. Dat de twist overigens nog niet was bijgelegd, blijkt uit de opmerking in de oorkonde dat de Zeeuwen niet bij de uitspraak waren komen opdagen. Uit de tekst leren we verder dat de Borseles wraak hadden genomen voor de moord op Wolfert. In de week voor Heilig Kruisdag (3 mei) van het jaar 1300 waren te Veere door Wolfens broers en kinderen misdaden gepleegd; zij hebben toen sommige van de moordenaars gedood. 11. Ook de Rijmkroniek en de Procurator vermelden

8 Willelmi capellani in Brederode, postea monachi el procuraloris Egmondensis, Chronicon, C. Pijnacker Hordijk, ed. (Amsterdam, 1904) 54-55.

9 Groot charlerboek der graaven van Holland, van Zeeland en heeren van Vriesland..., F. van Mieris, ed. (4dln.; Leiden 1753-1756) II, 83-84; een betere editie in Codex diplomatics Neerlandicus, 2e serie, 1-1 (1852) 12-15.

10 H. J. Smit, 'Het begin van de regeering der Henegouwsche graven (1299-1320)', Bijdragen voorde vaderlandsche geschiedenis en oudheidkunde, 7e reeks, II (1932) 29-71, in het bijzonder 31-32.

11 In de oorkonde wordt die gebeurtenis gebracht op het jaar 1301, waarschijn! ijk per abuis, want in de Rijmkroniek, VII, 97-106, lezen we dat in het voorjaar van 1300 enkele aanhangers van de graaf door Zeeuwen gevangen waren genomen en in Veere, de stad van de Borseles, waren geradbraakt. Daarop zal de bedoelde misdaad slaan. Zie ook B. Huydecoper, Rijmkronijk van Melis Stoke, met historie-, oudheid- 
de dood te Veere van een aantal Hollandse edelen, in een wraakneming vanwege de moord op Borsele, terwijl nog in februari 1332 oorkonden vanwege dit gebeuren werden uitgevaardigd ${ }^{12}$.

In 1309 werd de partijen dus een zoen opgelegd. Daarin werd door de scheidslieden bepaald dat de Borseles vanwege het in Veere misdrevene drieduizend pond Tournoois boete zouden betalen. Een boete van duizend pond Tournoois werd opgelegd aan de moordenaars van Wolfert van Borsele. Belangrijk voor ons is dat die moordenaars met naam en toenaam worden genoemd. Als de verantwoordelijken worden aangewezen enkele vertegenwoordigers van Hollandse adellijke geslachten, te weten Filips, Floris en Frank van Duivenvoorde, Filips en Dirk van Zandhorst, Wouter van Haarlem, Simon van Benthem, Filips Utemesse, Gisekin van Ammers, Vriese van der Mije, Jan van Sassenheim, Willem van der Lane en Gerard Ever. Dezen hebben Wolfens dood dus op hun geweten; sommigen van hen zijn later in Veere om het leven gebracht ${ }^{13}$. Als tweede bepalen de scheidslieden dat de poorters en de gemeente van Holland weliswaar aanwezig waren bij de moord, maar daaraan niet schuldig zijn bevonden. Zij waren 'uit liefde voor hun heer de graaf toegestroomd zonder te weten wat er aan de hand was', 'onnoseleke' zoals de tekst zegt. Zij mogen door de Borseles dan ook niet meer worden lastig gevallen vanwege dit voorval. Hieruit blijkt zonneklaar dat de familieleden van Wolfert bepaalde burgers in ieder geval steeds hebben beschouwd als medeschuldig aan diens dood. Waarschijnlijk is het de graaf die hier de poorterij met één pennestreek de schuld kwijtscheldt. Het is dus de versie van de Procurator die door de oorkonde van 1309 wordt bevestigd: Borsele is gedood door een aantal edelen en door het te hoop gelopen volk.

We keren weer terug naar de Rijmkroniek van Melis Stoke. Het is duidelijk dat Stoke in zijn verslag van de ondergang van Wolfert van Borsele de rol van enkele edelen heeft verzwegen. In zijn lezing is het het volk dat Borseles val teweegbrengt, en krijgt het volk dus alle krediet voor die in Stokes ogen positieve daad. Hoe onze auteur die moord ook toejuicht, het was wel degelijk een onrechtmatige daad, en men zou om die reden kunnen denken dat hij de betrokken edelen heeft willen beschermen door hun namen te verzwijgen. In dat geval had hij echter die edelen als een anonieme groep kunnen laten optreden, zoals hij ook deed met het volk. Het lijkt er dus op dat Stoke de rol van de adel bij deze ingrijpende gebeurtenis opzettelijk heeft verdonkeremaand. Die indruk wordt bevestigd wanneer men verder leest in de Rijmkroniek. Het is duidelijk dat overal in dat werk een zeer ondergeschikte rol is weggelegd voor de adel. Alleen bij in Stokes ogen ongunstige handelingen worden namen genoemd

en taalkundige aanmerkingen (3 dln.; Leiden, 1772) III, 77-79, en Smit, 'Begin regeering Henegouwsche graven', 31.

12 Stoke, Rijmkroniek, VII, 97-106; Procurator, Chronicon, 57 (alwaar de bewering dat sommigen van hen ten onrechte stierven, daar ze met die moord niets te maken hadden gehad); Van Mieris, Charterboek, $11,510,511$.

13 In de oorkonden van 6 en 14 februari 1331 (Van Mieris, Charterboek, II, 510, 511) worden als belangrijkste namen genoemd Dirk van Zandhorst, Floris en Wouter van Duivenvoorde, Gijsbrecht Bökel en Filips van Warmond. 
van betrokken edelen: de moord op Floris V is gepleegd door Gijsbrecht van Amstel, Herman van Woerden, Gerard van Velsen en andere, met name genoemde heren, de Zeeuwse rebellie tegen Floris V, Jan II en Willem III wordt door de adel gedragen, met Jan van Renesse als voornaamste verrader, in 1298 wordt Gijsbrecht van IJsselstein hardhandig tot de orde geroepen ${ }^{14}$.

Hoe weinig Stoke daarentegen genegen is de edelen te noemen wanneer zij zich gunstig onderscheiden, blijkt vooral bij zijn beschrijvingen van de veldslagen en belegeringen, waarvoor in de Rijmkroniek veel plaats is ingeruimd. Het was natuurlijk juist op dit terrein dat de adel een belangrijke rol speelde. Rond 1300 waren de zwaarbewapende ridders nog steeds de doorslaggevende factor op het slagveld. Daar bewezen zij steeds weer hun onmisbaarheid, daar lag hun raison d'être ${ }^{15}$. Dit blijkt bijvoorbeeld uit de beschrijving die Lodewijk van Velthem rond 1315 gaf van de Guldensporenslag, in zijn continuatie van de Spiegel historiael. Hierin vinden we het aandeel van veel bij het gevecht betrokken edelen gememoreerd: hun inbreng bij de beraadslagingen vóór de strijd, de plaats waar zij in de linie stonden opgesteld, hun daden tijdens het gevecht, en de manier waarop ze toen aan hun einde kwamen, terwijl een lijst van gesneuvelde Franse edelen het verslag besluit. Heldhaftige daden van het Vlaamse voetvolk worden ook vermeld, zoals de boogschutters die hun bogen tussen de benen van de aanstormende vijandelijke paarden wierpen, maar dat blijven anonymi, deel van de naamloze massa ${ }^{16}$.

Ook bij de Procurator speelt de adel wel degelijk een rol in de veldslagen. Gevechten worden door die auteur nergens uitvoerig beschreven, maar steeds maakt hij uitdrukkelijk melding van het feit dat de edelen aan de strijd deelnamen, en ook geeft hij regelmatig namen van gevallen ridders. Zo worden de opstandige Friezen in 1297 verslagen door het dappere optreden van de nobilitas Hollandie et Zeelandie, de adel van Holland en Zeeland, bij welk treffen de heer van Arkel en Jan van de Dortoghe sneuvelen ${ }^{17}$.

Dat in het Hollandse leger de adel een voorname rol speelde, en dat de graven zich van het doorslaggevende belang van de riddermacht goed bewust waren, blijkt overigens genoegzaam uit het oorkondenmateriaal. Wanneer er sprake is van een oorlogsdreiging doet de graaf zeer zijn best om zoveel mogelijk edelen achter zich te krijgen, door hun vooraf allerlei rechten te verlenen. Dit zien we in 1290, aan de vooravond van de strijd met de Vlamingen in Zeeland, wanneer Floris V de trouw koopt van de heren van Abbenbroek, Strijen, Egmond, Arkel, Haastrecht en van de edelen Hendrik

14 Stoke, Rijmkroniek, VI, 110-262.

15 J. F. Verbruggen, De krijgskunst in West-Europa in de Middeleeuwen (IXe tot begin XlVe eeuw) (Brussel, 1954).

16 Lodewijk van Velthem's voortzetting van de Spiegel historiael (1248-1316), H. vander Linden, W. de Vreese, R de Keyser, ed., II (Brussel, 1931) IV, 1493-2919 (capita 22-40). Het gedeelte over de Guldensporenslag is afzonderlijk uitgegeven, met een goede inleiding, in Lodewijk van Velthem, De Guldensporenslag. Een fragment uit de voortzetting van de Spiegel Historiael, W. Waterschoot, ed. (Den Haag, 1979). Voor een gezaghebbende studie over de slag zie J. F. Verbruggen, De slag der guldensporen. Bijdrage tot de geschiedenis van Vlaanderens vrijheidsoorlog, 1297-1305 (Antwerpen-Amsterdam, 1952).

17 Procurator, Chronicon, 53-54. 
Buffel en Wouter de Vriese. 18. Evenzo verwerft Jan I in 1298 steun onder de adel wanneer hij in conflict raakt met de bisschop van Utrecht ${ }^{19}$, en tracht in 1303 graaf Jan II de steun van de Hollandse adel te verwerven in het kader van de verwachte oorlog tegen de Vlamingen ${ }^{20}$. Ook Stoke maakt melding van het feit dat bij die gelegenheid de edelen met de graaf ter heervaart zijn getrokken, maar over hun aandeel in de strijd zwijgt hij ${ }^{21}$.

Bij Stoke dus is er geen sprake van het vermelden van krijgshandelingen door de adel, laat staan van loftuitingen jegens afzonderlijke ridders. In de Rijmkroniek vinden we bijvoorbeeld een uitvoerig verslag van het zojuist genoemde gevecht in 1297 tegen de Friezen, maar anders dan bij de Procurator is daar geen rol weggelegd voor de edelen. Stoke vermeldt ook hier dat zij als groep ter heervaart zijn opgeroepen voor de veldtocht, maar in de strijd zelf noemt hij hun optreden niet. Dat hij na afloop melding maakt van het sneuvelen van Arkel ('de goede heer Jan') is al heel uitzonderlijk $^{22}$. En zo gaat het steeds. De edelen, en ook de lagergeplaatste strijdenden, worden door hem vrijwel nooit met name genoemd; het geweld blijft anoniem. Slechts zelden worden individuele daden beschreven in de strijd, en dan betreft dat meestal naamloos voetvolk: een overmoedige Vlaming die zich bij het beleg van Zierikzee te ver naar voren waagt, een 'meester' die een blijde bedient en die gewond wordt door een vijandelijke steen. De gevechten worden door Stoke kort en schematisch beschreven, waarbij hij absoluut geen oog heeft voor het ridderlijk-sportieve aspect ervan, dat de adel juist zo aansprak, en dat in andere kronieken, zoals in die van Velthem, dan ook breed wordt uitgemeten. Men leze bijvoorbeeld Stokes beschrijving van de slag op Duiveland, waar op 20 maart 1304 een gecombineerde HollandsStichtse legermacht een zware nederlaag lijdt tegen de Vlamingen en de Zeeuwse opstandelingen $^{23}$. Ook daar geen woord over de aanwezigheid van de ridders. Dat die wel degelijk vertegenwoordigd waren, blijkt eerder in de Rijmkroniek, want daar wordt verteld hoe enkele dagen tevoren bijna vijftig Hollanders in het leger tot ridder zijn geslagen $^{24}$. Hun namen worden niet genoemd, uitgezonderd die van de grafelijke familieleden jonker Willem, de latere graaf Willem III, en Witte van Haamstede, bastaard van Floris V, en van de gunstelingen Nicolaas van Putten en Gerard van Voorne ${ }^{25}$. De adel streed op Duiveland wel degelijk mee, getuige ook de verliezen in zijn ran-

18 Oorkondenboek van Holland en Zeeland, L. Ph. C. van den Bergh, ed. (2 dln.; Amsterdam's-Gravenhage, 1866 (1868)-1873) II, nrs. 691, 692, 697, 700, 702-704, 710; zie H. Obreen, Floris V, graaf van Holland en Zeeland, heer van Friesland, 1256-1296 (Gent, 1907) 133.

19 Van den Bergh, Oorkondenboek, II, nr. 1040.

20 Van Mieris, Charterboek, II, 26-28, 32-34, 37

21 Stoke, Rijmkroniek, VIII, 580-590.

22 Stoke, Rijmkroniek, V, 962-1032.

23 Stoke, Rijmkroniek, VIII, 725-807. Over Stokes weergave van deze slag zie Burgers, 'Melis Stoke, literator of geschiedschrijver?', 26-28.

24 Stoke, Rijmkroniek, VIII, 660-679.

25 Zie A. Janse, 'Ridderslag en ridderlijkheid in laat-middeleeuws Holland', Bijdragen en mededelingen betreffende de geschiedenis der Nederlanden, CXII (1997) 317-335, m. n. 324-325. Aldaar wordt ook vermeld hoe Stoke de namen verzwijgt van de 'goede knapen' die werden geridderd bij de slag op de Gouwe, 10-11 augustus 1304 (Stoke, Rijmkroniek, IX, 945-949). Hiema meer over de bijzondere status van Nicolaas van Putten en Gerard van Voorne. 
gen; de Procurator schrijft dat bij die gelegenheid veel edelen sneuvelden, waaronder de Hollanders Nicolaas Persijn en Dirk van Haarlem en de Stichtenaren Willem van Horne, Dirk van Zuilen en Zweder van Beverweerd ${ }^{26}$.

Ook de rol van de adel in hun andere feodale taak, als raadgevers van de vorst en als medeverantwoordelijken voor het landsbestuur, wordt door Stoke geminimaliseerd ${ }^{27}$. Wanneer hij melding maakt van beraadslagingen van graaf en raad neemt hij steevast zijn toevlucht tot anonieme wendingen als 'men ghinc doe te rade' of 'men nam raet', zonder dus namen van raadslieden te noemen of zelfs maar melding te maken van het aandeel van de edelen in het overleg. Eén keer zegt hij, wanneer iets wordt besloten dat hem niet zint, dat hij zelf niet bij de beraadslaging was, omdat het anders niet zou zijn gebeurd. Dit was in de tijd dat Wolfert van Borsele de voornaamste raadsman van graaf Jan I was; bij een negatief bericht wordt de naam van die boeman weer wel genoemd $^{28}$. Ook Herman van Woerden wordt betiteld als de 'overste raet' van de graaf, ongetwijfeld om zijn verraderlijkheid des te scherper te laten uitkomen ${ }^{29}$. Uitzonderlijk is de vermelding in 1304 van Jan van Kruiningen die als 'overste raet' in het belegerde Zierikzee achterbleef om het bevel te voeren, terwijl jonker Willem zelf heimelijk ervandoorging ${ }^{30}$; over Jans rol tijdens het zeer uitvoerig beschreven beleg horen we verder trouwens weer niets ${ }^{31}$.

Deze anonimiteit van de raadslieden contrasteert sterk met de zojuist genoemde beraadslagingen in Velthems Spiegel historiael, waar de edelen met hun meningen ten tonele worden gevoerd, en zelfs met de Procurator, die ook nooit namen van raadslieden noemt, maar wel steeds vermeldt dat de graaf met zijn edelen overlegde en besluiten nam. Hij schrijft expressis verbis dat Willem in 1304 de raad van de aanzienlijksten van Holland inwon, terwijl hij even eerder melding maakt van edelen die op eigen gezag een wapenstilstand sloten met de Vlaamse vijand ${ }^{32}$. In de rond 1280 door een ander dan Stoke vervaardigde eerste Rijmkroniek speelt de adel eveneens een belangrijke rol in het politieke krachtenspel. Men zie daarin de beschrijving van de Loonse oorlog in de jaren 1203-1205, waarin Willem van Teilingen, Filips van Wassenaar, Jan van Rijswijk, Wouter van Egmond, Simon van Haarlem en anderen herhaaldelijk handelend optreden als steunpilaren van de landsheer of als door hem aangestelde legeraanvoerders ${ }^{33}$.

Dus ook de politieke rol van de adel wordt door Stoke systematisch verzwegen. De invloed van de edelen op het landsbestuur blijft veelal onvermeld, behalve wanneer

26 Procurator, Chronicon, 73.

27 Over de grafelijke raad, die in het laatste kwart van de dertiende eeuw uitgroeide tot een geïnstitutionaliseerd, door de adel bemand bestuurscollege, zie J. W. J. Burgers, 'De grafelijke raad in Holland in de dertiende eeuw. De evolutie van een centraal bestuursorgaan en de rol daarin van de grafelijke klerken', in voorbereiding.

28 Stoke, Rijmkroniek, V, 1265-1269, 1236, 1320-1322.

29 Stoke, Rijmkroniek, IV, 1163, 1183.

30 Stoke, Rijmkroniek, IX, 17-23.

31 Stoke, Rijmkroniek, IX, 128-210, 297-557.

32 Procurator, Chronicon, 71.

33 Rijmkroniek, III, 1-514; dit alles in navolging van de bron van de anonieme auteur, het Chronicon Egmundanum. 
er beslissingen worden genomen die Stokc niet bevallen. Dan krijgen opeens de raadgevers van de graaf de schuld. In de middeleeuwse geschiedschrijving is dat natuurlijk een algemeen gangbare wending, en waarschijnlijk verschuilt Stoke zich ook wel een beetje achter dit topos. Dat hij evenwel meent wat hij zegt, blijkt duidelijk uit de manier waarop hij die boodschap brengt. In lange tirades vaart hij uit tegen de onbetrouwbare elementen aan het hof: vleiers, verraders, die eerder hun eigen gewin op het oog hebben dan de belangen van de vorst. Men moest de personen 'hanghen bi der kele' die aan Floris V de raad gaven zijn aanspraken op het koninkrijk Schotland op te geven voor een som gelds ${ }^{34}$. Stoke wacht zich er wel voor zijn beschuldigende vinger naar met name genoemde personen uit te steken, maar wie de schoen past trekke hem aan: 'men weet wel wie het betreft' zegt hij letterlijk ('men weet een deel wie si sijn') ${ }^{35}$. Het zal inderdaad eenieder duidelijk zijn geweest dat met die onbetrouwbare hovelingen alleen de invloedrijkste edelen kunnen zijn bedoeld.

Stokes zwijgzaamheid over de positieve inbreng van de adel bij de gebeurtenissen, en zijn uitweiden over het negatieve optreden van edelen, zijn des te opmerkelijker wanneer we constateren dat Stoke juist heel expliciet is over de gunstige rol van het volk op de kritieke momenten in de Hollandse geschiedenis. Al bij oppervlakkige lezing van de Rijmkroniek valt op dat de auteur ervan de term 'het volk' in de mond bestorven ligt. Met het volk bedoelt Stoke soms alle ingezetenen van het graafschap, bijvoorbeeld wanneer hij beschrijft hoe in 1301 de Hollanders toestroomden om de Utrechtse bisschop te gaan bevechten, uit elke plaats, burgers en landvolk, zowel de adel als het gemeen: 'Also houde / Voer de meente uut elke stede, / Porters ende lantvolc mede / Beide edel ende ghemene diede ${ }^{\prime 36}$. Men zie ook de beschrijving van de oproep tot heervaart in het voorjaar van 1304, wanneer Zierikzee moet worden ontzet: Stoke schrijft dat velen toestroomden, ook personen die niet waren opgeroepen, en dat adel en burgerij op eigen kosten de wapenen opnamen ${ }^{37}$. In deze gevallen worden dus edelen en niet-edelen samen tot het volk gerekend. In die context prijst Stoke de adel, als deel van het volk. Het is immers juist de loyaliteit van het gehele volk ten opzichte van de vorst die in Stokes perceptie de legitimering vormt van de macht van de Henegouwse graven ${ }^{38}$.

Meestal echter gebruikt Stoke het woord 'vole' in de meer gangbare betekenis van 'gewone volk' de niet-edelen ${ }^{39}$. Hij makt daarbij een duidelijk onderscheid tussen de poorters, de stedelijke burgerij dus, en de 'gemeente', de plattelandsbevolking ${ }^{40}$.

34 Stoke, Rijmkroniek, IV, 793-805.

35 Stoke, Rijmkroniek, IV, 292/59.

36 Stoke, Rijmkroniek, VII, 882-885.

37 Stoke, Rijmkroniek, IX, 247-275.

38 Zie ook A. L. H. Hage, 'Drie geschiedschrijvers in het graafschap Holland en het 'ghemene voie": Stoke, Beke en De Clerc', in: R. E. V. Stuip, C. Vellekoop, ed., Gewone mensen in de Middeleeuwen. Bundel studies aangeboden aan F. W. N. Hugenholtz ter gelegenheid van zijn afscheid (Utrecht, 1987) 282-297, in het bijzonder 288-293.

39 Zie Hage, 'Drie geschiedschrijvers en het 'ghemene voie", 283, over de aanduidingen van het gewone volk in de bronnen.

40 Zie bijvoorbeeld Stoke, Rijmkroniek, X, 76-79. 
Zo spelen de landlieden een hoofdrol in zijn bekende beschrijving van de gevangenneming van en moord op graaf Floris $\mathrm{V}$ door enkele edelen, bij welke gelegenheid het volk eigener beweging toestroomde om de vorst uit handen van zijn belagers te bevrijden. Het volk, dat zijn bij deze gelegenheid de Kennemers, de Westfriezen en de Waterlanders; op het bericht van de aanslag

wert dat voie al in roere / Ende verwoet om dese voere. / De Kenemaren entie Vriesen mede / Ende Waterlanders voeren ter stede, / daer men hem dede verstaen / Dat haer here lach ghevaen ${ }^{41}$.

Even later zijn het de inwoners van Naarden die in een hinderlaag zijn gaan liggen om de vluchtende edelen met de graaf te onderscheppen, welke bevrijdingspoging Floris fataal zou worden ${ }^{42}$.

Is Stoke al positief over het optreden van dit landvolk, nog veel luvender laat hij zich steeds weer uit over de stedelingen. Vooral de burgers van Dordrecht en van Zierikzee worden door hem bij herhaling geprezen om hun standvastigheid in de strijd en om hun aanhankelijkheid jegens de graven, in het bijzonder de graven uit het Henegouwse huis, Jan II en Willem III. Toen in 1296 graaf Jan van Henegouwen hoorde van de dood van Floris V, stuurde hij zijn broer Gwijde naar Holland. Deze trok heimelijk naar Dordrecht. Toen de stedelingen vernamen dat hij was gearriveerd, waren zij dolgelukkig; zij 'hechten an hem allegader, / Also dat kint doet an den vader', en zij schaarden zich onmiddellijk achter hem, aldus Stoke ${ }^{43}$. Enige tijd later arriveerde de graaf van Kleef in Dordrecht, die het voorlopige bestuur in de hand wilde nemen, maar dat was volgens onze auteur tegen de zin van de burgers: 'dat mishagde den volke sere ${ }^{\prime 4}$. Daarop stuurde Gwijde bericht naar zijn broer, die kort daarna in eigen persoon naar Holland kwam. Stoke besteedt 22 versregels om de blijdschap van de Dordtenaren te schilderen bij de aankomst van graaf Jan. Hij verzekert ons wel twee maal dat men nog nooit een volk zo blij zag als de Dordtse burgers toen ze hoorden dat Jan in Geertruidenberg was gearriveerd. Zij hoopten dat hij de dood van hun heer graaf Floris zou wreken, en binnen drie dagen hadden zich wel drieduizend man bij hem aangesloten ${ }^{45}$. Toen begin 1297 Jan I vanuit Engeland in het graafschap arriveerde, was de rol van Jan van Henegouwen voorlopig uitgespeeld, omdat de jonge graaf zich in de macht van de Zeeuwse edelen bevond. Toen de Henegouwer verzocht om een onderhoud met Jan, werd hem te verstaan gegeven dat zulks slechts mogelijk was wanneer hij met een klein escorte naar Zeeland kwam. Daar ging hij natuurlijk niet op in, hoewel de Dordtenaren hem verzekerden dat ze hem allen gewapenderhand zouden vergezellen ${ }^{46}$. Nergens in de Rijmkroniek vindt men dergelijke herhaalde verzekeringen van aanhankelijkheidsbetuigingen jegens de graaf

41 Stoke, Rijmkroniek, $V, \quad 1-6$.

42 Stoke, Rijmkroniek, V, 30-35.

43 Stoke, Rijmkroniek, V, 274-302.

44 Stoke, Rijmkroniek, V, 490.

45 Stoke, Rijmkroniek, V, 324-341.

46 Stoke, Rijmkroniek, V, 851 -907. 
door edelen; zo wordt in de laatstgenoemde passage alieen tussen neus en lippen door gemeld dat de heer van Arkel trouw was aan Jan van Henegouwen.

Eveneens zeer uitgesproken is Stoke over het voorbeeldige gedrag van poorters in het heetst van de strijd. In 1303 en 1304 wordt Zierikzee drie maal belegerd door de Vlamingen, en steeds onderscheiden de burgers zich door heldhaftig gedrag, dat in de Rijmkroniek alle ruimte krijgt; Stoke heeft het zelfs over 'wonderen' die in de strijd zijn verricht door de Zierikzeese poorters ${ }^{47}$. Keer op keer weten zij de vijand van de muren weg te houden, en het eerste beleg wordt zelfs beëindigd doordat de burgers de Vlamingen via een uitval weten te verrassen en te verslaan ${ }^{48}$. Een jaar later bestoken de Vlamingen met zware artillerie de stad, maar de poorters schieten terug, waarbij de vrouwen de munitie aanslepen en de in brand geschoten huizen blussen. Ook wanneer de situatie benauwd wordt en de honger dreigt, houdt de stad stand, hoewel het vee uit nood het stro van de daken moet eten ${ }^{49}$. Bij offensieve acties onderscheiden inwoners van Zierikzee zich eveneens; wanneer op 9 maart 1304 een bestand met de Vlamingen afloopt, trekken de burgers onmiddellijk uit naar een nabijgelegen vijandelijke versterking, die ze prompt veroveren ${ }^{50}$. Ook de poorters van andere steden, inclusief de vrouwen, staan militair hun mannetje. Na een bliksemsnelle veldtocht hebben de Vlamingen in het voorjaar van 1304 heel Holland bezet tot aan de Haarlemmerhout; alle steden, behalve Dordrecht, hebben zich aan hen onderworpen. Nadat in Haarlem Witte van Haamstede is geland scheppen de graafgezinden weer moed. De poorters van Leiden slagen erin hun in Gouda gegijzelde medeburgers te bevrijden en verjagen de vijand uit de stad; ook de inwoners van Delft en Delfland weten de Vlamingen te verdrijven, evenals die van Schiedam, waar de vrouwen blijkbaar het initiatief nemen ${ }^{51}$.

Uit deze voorbeelden blijkt dat het optreden van de burgerij in de strijd door Stoke uitvoerig en lovend wordt beschreven, in tegenstelling tot de eerder gesignaleerde verwaarlozing door hem van de rol van de adel op het slagveld. Nu moet worden gezegd dat veel strijdbeschrijvingen in de Rijmkroniek juist handelen over gevechten waar de ridder te paard slecht uit de voeten kon: we vinden hier veel belegeringen van steden en kastelen, en de door Stoke uitvoerig behandelde beslissende slag tegen de Vlamingen werd op 10 en 11 augustus 1304 geleverd op het water van de Gouwe, de stroom tussen Schouwen en Duiveland. Toch kunnen we niet anders dan veronderstellen dat ook bij die gevechtshandelingen de adel prominent aanwezig zal zijn geweest, maar dat we in de Rijmkroniek daarvan bitter weinig terugvinden, terwijl de heldendaden van het gewone volk breed worden uitgemeten.

Samenvattend kunnen we de houding van Melis Stoke ten opzichte van de adel aldus omschrijven. Centraal in Stokes optiek staan de Hollandse graven uit het Henegouwse huis, Jan II en Willem III. Dezen hadden aanvankelijk de nodige moeite om het hoofd

47 Stoke, Rijmkroniek, IX, 573-580.

48 Stoke, Rijmkroniek, VIII, 233-382.

49 Stoke, Rijmkroniek, IX, 128-210, 297-580.

50 Stoke, Rijmkroniek, VIII, 601-619.

51 Stoke, Rijmkroniek, VIII, 1177-1213. 
boven water te houden, vanwege de Zeeuwse opstand en de oorlog met Vlaanderen. Bij die moeilijkheden werden ze volgens Stoke van harte gesteund door 'het volk', alle inwoners van het graafschap. Vaker gebruikt Stoke de term 'vole' in een meer beperkte betekenis, en duidt hij daarmee de burgers en landlieden aan. In Stokes relaas lezen we dat het vooral de poorters van de steden zijn die de grootste rol spelen bij de gebeurtenissen. Zij zijn steeds loyaal ten opzichte van de graaf, en hun militaire prestaties worden breed uitgemeten. Voor de edelen heeft Stoke daarentegen weinig waardering, en ook weinig aandacht. Zij treden eigenlijk pas sterk op de voorgrond wanneer zij zich negatief onderscheiden: Gijsbrecht van Amstel, Herman van Woerden en Gerard van Velsen, de moordenaars van graaf Floris V, worden uitvoerig voor het voetlicht gebracht en zeer ongunstig afgeschilderd. Dat geldt eveneens voor Wolfert van Borsele en Jan van Renesse, de aanvoerders van de verraderlijke proVlaamse adel. Stoke gaat zelfs zover te beweren dat Borsele en Renesse medeplichtig waren aan de moord op Floris. De edelen die daarentegen de graaf trouw dienden en dapper zullen hebben gevochten in de talrijke gevechten, worden door Stoke nauwelijks beloond met waarderende woorden. Hun politieke en militaire optreden wordt door hem vrijwel doodgezwegen. Raadgevers aan het hof worden in de Rijmkroniek ofwel niet met name genoemd ofwel gebrandmerkt als de drijvende kracht achter specifieke verkeerde beslissingen, terwijl raadslieden in het algemeen worden afgeschilderd als op eigen gewin beluste stokebranden.

Men moet niet menen dat Melis Stoke zich dergelijke vrijpostige opinies vanzelfsprekend kon permitteren. Anders dan een moderne auteur, had hij terdege rekening te houden met zijn opdrachtgever en zijn publiek ${ }^{52}$. De Rijmkroniek was een in opdracht van de graaf geschreven werk, dat ongetwijfeld aan het hof werd voorgedragen op de lange winteravonden. Het hof was nu juist de plaats waar de adel het gezelschap van de landsheer opzocht, en bij het voorlezen van de kroniek zal dan ook vaak of steeds een aantal edelen aanwezig zijn geweest. In die sociale context moet het voor de edelen, die toch al bijzonder gevoelig waren voor zaken betreffende eer en schande, nauwelijks te verteren zijn geweest dat zij in die officiële geschiedschrijving van het graafschap er zo slecht vanaf kwamen; hun gloriedaden in de strijd en hun politieke invloed werden verzwegen, hun misstappen werden daarentegen vol voor het voetlicht gebracht. Tot overmaat van ramp werd het optreden van het volk, en met name van de door de adel waarschijnlijk als reële bedreiging gevoelde burgerij, steeds uitvoerig en positief beschreven.

52 Over de relatie tussen auteur, opdrachtgever en publiek zie enkele artikelen herdrukt in F. van Oostrom, Aanvaard dit werk. Over middelnederlandse auteurs en hun publiek (Amsterdam, 1992), in het bijzonder 'Hoofse cultuur en litteratuur', Ibidem, 21-40, met name 36-39, en 'De vrijheid van de middelnederlandse dichter', Ibidem 81-95, met name 91-92, 95. Daar wordt duidelijk gemaakt dat de literatuur binnen 'de kleine kosmos' van het hof fungeerde als een 'ideologisch bindmiddel', ter 'collectieve zelfbevestiging'. In die situatie had de auteur wel enige vrijheid tot relativering en oppositie, maar in het algemeen diende hij zich te conformeren aan de opvattingen van zijn opdrachtgever en zijn publiek. Mijns inziens geldt dat a fortiori voor de geschiedschrijver Melis Stoke, die in zijn werk een politieke boodschap uitdroeg, welke in de toen heersende moeilijke omstandigheden zeer gevoelig lag. Bovendien heeft het er alle schijn van dat Stoke, in zijn overduidelijke hondentrouw jegens de Henegouwse graven, hun standpunten met volle overtuiging heeft uitgedragen. 
Hoe is het nu te verklaren dat Melis Stokc in een dergelijke voordrachtsituatie deze controversiële boodschap kon verkondigen? Hij moet, dat kan niet anders, herhaaldelijk pijnlijk hard hebben getrapt op de toch al gevoelige tenen van zijn machtige toehoorders. Dat die spanning tussen auteur en publiek inderdaad bestond, blijkt onweerlegbaar uit enkele passages van de Rijmkroniek. Wanneer Stoke weer eens is uitgevaren tegen de zelfzuchtige hovelingen die de eer van de vorst aan hun laars lappen wanneer ze daar zelf voordeel bij hebben, voelt hij blijkbaar aan dat hij nu wel erg ver is gegaan, want hij besluit zijn tirade met een smeekbede aan God dat men zich niet op hem zou wreken vanwege zijn woorden: 'God moet mi sijnre hulpe onnen, / Dat men niet an mi moet wreken / Mijn dichten ende mijn naspreken ${ }^{153}$.

Het staat vast dat Stoke met name signalen kreeg vanuit zijn publiek dat men moeite had met de wijze waarop in de Rijmkroniek de militaire rol van de adel onzichtbaar was gemaakt; niet vreemd, want zoals gezegd ontleenden de ridders hun bestaansrecht juist aan het optreden op het slagveld. Die morrende geluiden blijken aan het einde van de kroniek. Stoke heeft dan uitvoerig verslag gedaan van de beslissende zeeslag tegen de Vlamingen en de Zeeuwse ballingen, die in augustus 1304 op het water van de Gouwe was geleverd en die was uitgedraaid op een klinkende overwinning voor de Hollanders (en de geallieerde Franse vloot onder aanvoering van admiraal Grimaldi, maar ook daaraan maakt Stoke niet al te veel woorden vuil). Zoals elders geeft onze auteur ook nu weer geen namen van edelen die zich in de strijd hebben onderscheiden. $\mathrm{Nu}$ evenwel gaat Stoke uitvoerig in op de reden voor die omissie $^{54}$. Hij zegt tot zijn publiek:

$\mathrm{Nu}$ so moghedi mi vraghen, / Waerom dat ie niet en noeme / Die vanden stride was die bloeme, / Of die quaetste, of die beste, / Of die vortste, of die leste?

Hij geeft zelf het antwoord: 'Mij dunkt, ik prijs ze allemaal samen; dat lijkt mij de beste manier. En ook wil ik niet kwaadspreken van mijn tegenstanders, behalve dan van degenen die zich 's nachts aan de strijd hebben onttrokken'. Volgens hem waren er nogal wat Hollanders die niet aan vechten toe waren gekomen, en die er graag vandoor zouden zijn gegaan; 'dat togheden si wel in ghelate', dat was duidelijk van hun gezicht af te lezen. 'Bovendien', zegt Stoke, 'wanneer ik sommigen zou prijzen en anderen niet, dan zou men weer zeggen dat ik uit afgunst of vanwege steekpenningen zo handelde. Nee, ik durf wel te stellen dat iedereen goed vocht: adel, poorters en ook het gemeen; ik weet niet wat ik daar meer over moet zeggen'. Desondanks gaat hij nog een hele tijd door met zich te verontschuldigingen. Uiteindelijk heeft hij 112 versregels nodig om te zeggen dat hij er niet over piekert om de strijders met naam en toenaam te prijzen of te laken voor hun aandeel in het gevecht. Hij noemt een hele reeks redenen voor die onwil, welke variëren van angst voor repressailles op zijn persoon tot morele gronden - zo zijn lofprijzingen karakterbedervend, en kan voortijdige eer bij een latere misstap verkeren in schande. We krijgen evenwel niet de

53 Stoke, Rijmkroniek, IV, 292/62-64.

54 Stoke, Rijmkroniek, X, 40-151. 
indruk dat hij hier het achterste van tong laat zien; de verschillende overwegingen vormen een weinig coherent geheel.

We stellen dus nogmaals de vraag: waarom kleineert Stoke opzettelijk de rol van de adel, terwijl hij met name de burgerij regelmatig looft? Een verklaring zou gevonden kunnen worden in Stokes eigen achtergrond. We zagen dat hij in de jaren 1296-1299 werkzaam was in Dordrecht als stadsklerk, de hoogste ambtenaar van de stad. Bovendien zijn er sterke aanwijzingen dat hij nauwe banden had met Zierikzee; mogelijk was dat na 1300 zijn standplaats wanneer hij niet met het grafelijk hof op reis was. Stokes genegenheid voor de burgerij, en dan speciaal voor de poorters van deze twee steden, is zo goed verklaarbaar.

Stokes eigen voorkeuren zullen wel een rol hebben gespeeld, maar kunnen nooit de enige of zelfs maar de voornaamste verklaring zijn voor zijn opvallend negatieve kijk op de adel. De edelen vormden samen met de graaf immers zijn eerstbeoogde publiek, en we zagen dat zij inderdaad die opstelling niet zomaar accepteerden. Het kan niet anders dan dat Stoke in deze werd gesteund door zijn opdrachtgevers, de graven Jan II en Willem III. De Rijmkroniek draagt dus een bepaalde grafelijke boodschap uit, en die is niet gunstig voor de adel. De graven zagen de basis van hun macht vooral liggen bij de gewone volk, en dan met name bij de steden. De stedelingen beschouwden zij als hun belangrijkste aanhangers en als hun militaire steun en toeverlaat. Deels was die opvatting gebaseerd op de werkelijk bestaande toestand. De steden waren in de tweede helft van de dertiende eeuw snel uitgegroeid tot economisch en daarmee ook politiek invloedrijke entiteiten. Juist de Henegouwse graven werden al vóór hun opvolging in Holland gesteund door steden als Dordrecht en Schiedam en daarna ook door Zierikzee ${ }^{55}$. In de Zeeuwse opstand en de oorlog tegen Vlaanderen waren de steden de voor de graaf zekere steunpunten geweest, die zich ook militair onderscheidden.

Maar ook voor de graven kan de liefde voor de steden nooit een reden zijn geweest om de adel zo opvallend te kleineren. We zagen immers dat de adel militair wel degelijk een vooraanstaande rol vervulde, en uit de oorkonden weten we dat ook onder de Henegouwse graven de edelen prominent aanwezig waren in het landsbestuur. Er moet dus een bewuste politiek van de graven in het spel zijn, die erop gericht was de adel een toontje lager te laten zingen. De achtergronden van die politiek worden nergens expliciet verwoord in het ons ter beschikking staande bronnenmateriaal. Zij zijn wel te reconstrueren, en daarvoor moeten we iets terug in de tijd.

Het is een understatement wanneer we zeggen dat graaf Floris V veel te stellen heeft gehad met de adel. Tijdens zijn minderjarigheid in de jaren zestig kwam het tot een regelrechte oorlog tussen twee adelsfacties, in de jaren zeventig raakte hij verwikkeld in een twist met zijn machtige Henegouwse verwanten die werden gesteund door enkele Hollandse edelen, zoals Dirk van Teilingen, in de jaren tachtig voerde hij oorlog met edelen in het Stichts-Hollandse grensgebied, de heren van Amstel en Woerden, en in de jaren negentig was vrijwel de hele Zeeuwse adel in opstand tegen

55 Over de politieke rol van de steden rond 1300 zie laatstelijk Burgers, 'Grafelijke raad'. Ook Floris V kon in moeilijke tijden rekenen op landvolk en steden, contra de adel: Stoke, Rijmkroniek, IV, 613-627. 
zijn gezag. De edelen drukten dus een bijzonder sterk stempel op Floris' politiek; steeds had de graaf te kampen met hun twistziek en opstandig gedrag, en daaraan zou hij uiteindelijk zelfs ten gronde gaan. Daarbij ging het niet steeds tussen graaf en adel; ook de edelen onderling waren verdeeld in elkaar soms te zwaard bestrijdende partijen, waarbij de graaf dan weer garen kon spinnen door de facties tegen elkaar uit te spelen $^{56}$. Na Floris' dood werd de invloed van de adel nog groter: de zwakke graaf Jan I stond eerst onder controle van Jan van Renesse en daarna van Wolfen van Borsele. Ook in die periode was strijd tussen adelsfacties aan de orde van de dag; we zagen al dat Borsele daarvan het slachtoffer werd.

De graven van het Henegouwse huis werden vermoedelijk eveneens geconfronteerd met een factiestrijd tussen adelsgroeperingen. Stoke maakt van dergelijke twisten niet expliciet melding, maar uit enkele uitlatingen van hem blijkt wel dat de situatie aan het hof bij tijd en wijle explosief was. Illustratief is zijn uitweiding over sommige hovelingen, die zich gepasseerd voelen door de graaf, terwijl ze het liefst een monopoliepositie zouden hebben in diens entourage; daarom proberen zij dag en nacht onrust te stichten. Volgens Stoke deed de vorst er beter aan dergelijke elementen, die zich uit eigenbelang omhoog probeerden te werken, van het hof te verjagen. Stoke noemt geen namen, maar mengt zich met die uitspraken wel degelijk in de factiestrijd, getuige zijn eerder geciteerde verzuchting dat hij hoopt dat men zich niet vanwege zijn woorden op hem zou wreken ${ }^{57}$. Hoeveel indruk de partijstrijd onder de graven Jan I en Jan II heeft gemaakt, blijkt uit het feit dat in de laatste decennia van de veertiende eeuw Willem van Hildegaersberch daarvan nog melding maakt in zijn gedicht Van tregiment van goeden heren; pas onder Willem III werd volgens Hildegaersberch de rust hersteld ${ }^{58}$.

Toen graaf Jan II met de verdeelde adel te maken kreeg, was de situatie evenwel drastisch gewijzigd ten opzichte van de toestand onder zijn voorgangers. De rangen van de edelen waren namelijk sterk uitgedund, ten gevolge van verschillende factoren. Ten eerste wilde het toeval dat aan het einde van de dertiende eeuw enkele vooraanstaande adellijke families een periode van neergang kenden. Zo was in 1283 de hoofdtak van de Teilingens uitgestorven, zodat het bezit van het geslacht aan de grafelijkheid was vervallen ${ }^{59}$. De machtige Voornes, de burggraven van Zeeland, wa-

56 Zie over de relatie russen de graaf en de edelen J. M. A. Coenen, Graaf en grafelijkheid. Een onderzoek naar de graven van Holland en hun omgeving in de dertiende eeuw (Proefschrift Utrecht 1986; S. 1., s. a.). 57 Stoke, Rijmkroniek, IV, 292/6-64. Uit die angst voor repressailles blijkt tevens dat Stoke hier refereert aan de actuele situatie aan het hof, dus die in de jaren 1301-1302, en niet over de toestand tijdens de jonge jaren van graaf Floris V, binnen welke context hij de uitweiding over hooggeplaatste onruststokers heeft ingevoegd.

58 Gedichten van Willem van Hildegaersberch, W. Bisschop, E. Verwijs, ed. ('s-Gravenhage, 1870; ongew. herdr. Utrecht, 1981) 101-102, nr. LI. Daar is sprake van een goede vorst die stierf, waarna het land ten prooi viel aan partijschap en strijd (verzen 42-43: 'Tvolck ghinc onderlinghe striden, / Die heren scheyden in partyen'), aan welke situatie een einde werd gemaakt door een nieuwe jonge vorst, die rusten voorspoed bracht. De uitgevers maken in de inleiding, Ibidem, XIII, duidelijk dat Hildegaersberch met de twee niet met name genoemde goede graven Floris V en Willem III bedoelt, en dal de periode van burgeroorlog en partijstrijd dus viel in de russengelegen periode.

59 R. Fruin, 'De jongere tak der Van Teylingens, in; Idem, Verspreide geschriften, VIII ('s-Gravenhage, 1903) 157-175, in het bijzonder 157-165. 
ren met het overlijden in 1287 van heer Albrecht zonder sterke leiding; de minderjarige opvolger Gerard stond eerst onder voogdij van zijn moeder, Catharina van Durbuy, die waarschijnlijk sterk onder - amoureuze — invloed stond van Floris V. Gerard werd aan het grafelijk hof opgevoed, en toen hij rond 1296 zelfstandig zijn gezag uit begon te oefenen, betoonde hij zich een trouw volgeling van de graaf. Gerard is dan ook een van de weinige edelen, samen met Nicolaas van Putten, die door Stoke met enige regelmaat in positieve zin worden genoemd ${ }^{60}$. Ook Nicolaas was nog jong; in de jaren tachtig stond hij, het minderjarige 'kind van Putten', nog onder voogdij; in 1291 werd hij mondig.

De neergang van de adel werd vooral bewerkt door een tweede omstandigheid, namelijk de rampen die in de jaren negentig het graafschap troffen. Vrijwel de complete Zeeuwse adel ging in 1290 een leenband aan met de Vlaamse graaf, die eropuit was het omstreden Zeeland bewesten Schelde aan het de facto al lang vigerende Hollandse gezag te onttrekken. In 1300 rebelleerde de adel opnieuw, ging na de nederlaag van 1 januari 1301 in ballingschap, en vocht in de oorlog van 1303-1304 zij aan zij met de Vlaamse invallers. Dit gedrag, door Melis Stoke herhaaldelijk getypeerd met het woord 'verraad', maakte dat zij hun politieke invloed bij de grafelijkheid voorlopig hadden verspeeld. De grootste misdaad evenwel van de edelen betrof natuurlijk hun optreden in 1296. De moord op Floris V maakte direct een einde aan de positie van een aantal adelsfamilies, die van Amstel, Woerden, Velzen, maar ook leden van de geslachten van Cuyk, Heusden, Teilingen, Zaanden, Benschop en Uternesse waren bij de aanslag betrokken. Bovendien kwam door dit gebeuren een groot aantal families, die zelf niets met de aanslag van doen hadden, in een afhankelijke positie te verkeren tegenover de grafelijkheid. In 1285 en 1288 immers hadden zij zich met hun lijf en goed borg gesteld bij de onderwerping van Gijsbrecht van Amstel en Herman van Woerden, en door het verraad van die heren waren zij nu aan de genade van de graaf overgeleverd ${ }^{61}$. Dat die borgstellingen geen dode letter waren en wel degelijk consequenties hadden, met name van financiële aard, blijkt uit het oorkondenmateriaal. Zo scheldt graafian II in juni 1303 de erfgenamen van heer

60 Zie bijv. Stoke, Rijmkroniek, VIII, 660-677, 1048-1049, 1065 vlg., 1215-1216. Over de positie van Gerard en Nicolaas bij de grafelijkheid zie Smit, 'Begin regeering Henegouwsche graven', 32-33.

61 Van den Bergh, Oorkondenboek, II, nrs. 571 en 632. De borgen voor Amstel zijn: de Hollanders Jacob van den Woude, Gijsbrecht Bökel en zijn zoon Gijsbrecht, Gijsbrecht Bot van der Eem, Wouter en Willem broers van Simon van Haarlem, Jan zoon van de heer van Teilingen, Dirk Simonszoon van Teilingen, Willem van Oegstgeest, Floris Floriszoon van der Woerd, Troveis van Moordrecht en Jan van Tolloisen, voorts elf heren uit het Sticht, terwijl enkelen zich verplichten bij een zoenbreuk de graaf met gewapende volgelingen te hulp te komen: Hendrik van der Lek met 25 man, Willem van Strijen met 20 man, Harbaren van der Lede met 20 man, Jan van de Lede met 15 man, Dirk van Wassenaar met 10 man, Hendrik burggraaf van Leiden met 10 man en Gerard van Velsen met 20 man. De borgen voor Woerden: de Hollanders Harbaren van Haastrecht, Gijsbrecht Bot van der Eem, zijn broer Gijsbrecht Bökel, Jacob van der Woude, Dirk Simonszoon van Teilingen en Troveis van Moordrecht, voorts 14 Stichtse edelen, terwijl bij zoenbreuk gewapende hulp wordt beloofd door Hendrik van der Lek met 20 man, Jan van Heusden met 15 man, Willem van Home met 20 man, Jan van Cuyk met 20 man, Arnout van Herlaar met 10 man, Arnout van der Sluis met 5 man, Willem van Strijen met 10 man, Jan van der Lede met 10 man en Willem van Linschoten met 10 man. 
Jacob van de Woude vrij van alle aanspraken die voortvloeiden uit diens borgtocht vanwege de genoemde verraders ${ }^{62}$. Ook het geslacht Bökel werd vanwege die borgstellingen na 1296 verdreven uit zijn bezittingen ${ }^{63}$.

Het belangrijkste gevolg van de moord op Floris lijkt mij echter dat de adel als groep was gecompromitteerd. Alle edelen werden op die misdaad aangezien. Dit lezen we expliciet bij de Procurator, die schrijft dat als reactie op de gevangenneming van de graaf het volk zelf in actie kwam, omdat die wandaad alle edelen werd aangerekend $^{64}$. Uit een oorkonde van 2 augustus 1296 blijkt dat in de dagen na de moord Hollandse edelen onder verdenking van medeplichtigheid stonden en gedwongen waren zich in Haarlem in bewaring te begeven; dit betrof Dirk van Brederode, Willem van Egmond, Nicolaas Persijn, Gerard van Egmond, Willem van Haarlem, Jan van Teilingen en Gerard van Heemskerk, allen leden van aanzienlijke families ${ }^{65}$. Toen enkele edelen zich aan het hoofd stelden van het legertje dat het deel van de moordenaars belegerde dat zich op kasteel Kronenburg had verschanst, laaide het wantrouwen weer op; Stoke schrijft dat het volk ervan overtuigd was dat hun aanvoerders erop uit waren de moordenaars te laten ontsnappen ${ }^{66}$. Het lijdt geen twijfel dat de Henegouwers deze tegen de adel gerichte stemming hebben uitgebuit. Dit zien we in de oorkonden, waarin vanaf 1299 te pas en te onpas sprake is van bepalingen tegen de de verraders van 1296 en tegen allen die aan hen hulp zouden verlenen ${ }^{67}$. Dat zien we ook in de Rijmkroniek, waar Stoke de aanslag op Floris V niet voor niets uitbouwt tot een van de centrale thema's van het verhaal, en waar hij zich de nodige moeite getroost om tegenstanders van de Henegouwers medeplichtigheid aan de moord in de schoenen te schuiven; de namen van Wolfen van Borsele en Jan van Renesse zijn in dit verband al gevallen. Graaf Jan II heeft zich ook daadwerkelijk bedreigd gevoeld door sommige edelen, getuige zijn op 14 juli 1300 gegeven opdracht aan zijn broer Gwijde, dat die een onderzoek moest instellen naar Nicolaas Persijn, Hendrik van

62 P. H. J. van der Laan, 'Een middeleeuwse borgtocht. Kanttekeningen bij een oorkonde van graaf Jan II van Holland en Zeeland', Tijdschrift voor geschiedenis, LXXVIII (1965) 179-186.

63 T. S. Jansma, 'De oudste geschiedenis van Rotterdam', in: Idem, Tekst en uitleg. Historische opstellen aangeboden aan de schrijver bij zijn aftreden als hoogleraar aan de Universiteit van Amsterdam (Den Haag, 1974) 1-34, !n het bijzonder 5-8, 11. Over dezelfde kwestie R.Fruin, 'De oudheid van Rotterdam', in: Idem, Verspreide geschriften, VI ('s-Gravenhage, 1902) 1-74, in het bijzonder 32-37, 67-69. De onaangename consequenties van een borgstelling ondervonden ook Jan van Schengen en Nicolaas van Cats, die borg waren voor Jan van Renesse en die na diens verbanning in 1297 in leisting moest gaan (Van den Bergh, Oorkondenboek, II, nrs. 1019, 1055; vergelijk Stoke, Rijmkroniek, V, 1165-1171).

64 Procurator, Chronicon, 47.

65 Van den Bergh, Oorkondenboek, II, nr. 954. Zie ook Stoke, Rijmkroniek, IV, 1235-1242, waar wordt gesteld dat 'velen van het land' op de hoogte waren van de samenzwering tegen de graaf.

66 Stoke, Rijmkroniek, V, 313-348.

67 Zie Van den Bergh, Oorkondenboek, II, nrs. 1093, 1095. Bij de vrede met Brabant, gesloten in april 1307, werd de moordenaars van Floris V de toegang tot Holland ontzegd; Smit, 'Begin regeering Henegouwsche graven', 32. De positie van deze ballingen vormde nog steeds een punt bij de onderhandelingen in 1310 met Vlaanderen; S.A. Waller Zeper, Jan van Henegouwen, heer van Beaumont. Bijdrage tot de geschiedenis der Nederlanden in de eerste helft der veertiende eeuw ('s-Gravenhage, 1914) 30-40. Nog in 1323 is men bezig om tot een verzoening te komen met de ballingen van '1296', in dit geval met die uit Amstelland; Van Mieris, Charterboek, II, 255. 
Alkemade, Dirk heer Simons zoon van Teilingen, Jan van der Wateringe, Jan van Noordwijk, Jan Splinter en van Frank van Hoylande, van wie een vermoeden van ontrouw was gerezen ${ }^{68}$.

$\mathrm{Nu}$ blijkt uit de bronnen duidelijk dat niet alle edelen hun krediet bij de graven hadden verspeeld. Er was een groep die door de Henegouwse graven vanaf het begin van hun regering in Holland is begunstigd. Dit betreft vooral enkele onderling verwante geslachten die zijn voortgesproten uit een jongere zijlinie van de Wassenaars. Het zijn de Duivenvoordes, Polanens, Zandhorsten, Raaphorsten; de leden van die geslachten maken in ieder geval onder Willem III snel carrière in grafelijke dienst. Zij bekleden de lucratieve ambten, zijn lid van de grafelijke raad, en weten zich in de eerste helft van de veertiende eeuw tot grote rijkdom en hoog aanzien op te werken. Vermoedelijk hebben zij ook al bij graaf Jan II in de gunst gestaan, want het zijn juist de leden van deze groep die in 1299 verantwoordelijk waren voor de moord op Wolfert van Borsele, met welke daad zij immers Jan van Henegouwen op het Hollandse regeringskussen brachten ${ }^{69}$. Toch zullen Jan II en Willem III niet alleen uit dankbaarheid deze jonge adel hebben begunstigd. Zij waren daartoe door de genoemde omstandigheden ook wel gedwongen: bij deze edelen vonden ze steun tegenover de hun vijandige Borseles en de rest van de Zeeuwse adel, die na de moord op Wolfert immers eveneens onverzoenlijk stonden tegenover deze geslachten. Bovendien zullen de edelen uit deze jonge takken uit eigenbelang de graaf van harte hebben gesteund tegen de aspiraties van de niet in ongenade gevallen of weer in genade aangenomen leden van de voorheen aanzienlijkste geslachten, die door de Henegouwers werden gewantrouwd en die zich aan het hof achtergesteld voelden. Hier lag mogelijk de bron van de factiestrijd in deze periode.

Zo heeft Jan II vermoedelijk van de nood een deugd gemaakt. Toen hij eind 1299 graaf van Holland werd, was juist een groot deel van de oproerige oude adel in diskrediet geraakt. Dat stelde hem voor een probleem, want hij had in die roerige tijden de militaire kracht en de bestuurservaring van de edelen hard nodig. Zijn oplossing was om het tweede echelon edelen tot de hoge posities te verheffen. De jonge adelsgeslachten waren lang niet zo bedreigend voor de grafelijke macht als de oude adel was geweest, en in Zeeland nog steeds was. Zij hoefden niet op te komen voor eigen dynastieke belangen, en nog belangrijker, zij misten de eigen solide machtsbasis in de vorm van uitgestrekte goederen met de daarbij behorende inkomsten ${ }^{70}$. De graaf had hun steun weliswaar nodig, maar voor hun opkomst waren zij van hun kant in

68 Van Mieris, Charierboek, II, 11. Van een van deze edelen, te weten Jan van Noordwijk, is een oorkonde bekend d. d. 4 augustus 1300, waarin die zich trouw aan de graaf verklaart (Ibidem, 15).

69 Aldus al het belangrijke artikel van Smit, 'Begin regeering Henegouwsche graven', 32-44, alwaar, 32, wel wat al te gemakkelijk wordt gesteld dat de hele Hollandse adel 'eensgezind' de Henegouwers steunde; uit het vervolg blijkt dat het, naast Jan van Beaumont, broer van Jan II, wijbisschop Jacob van Zuden en de heren van Voome en Putten, het voornamelijk de jonge geslachten waren waarop de graven steunden.

70 Over de verschillen in rijkdom tussen oude en nieuwe adel, in dit geval ten tijde van Floris V, zie A. Janse, 'Adel en ridderschap in de tweede helft van de dertiende eeuw', in: D. E. H. de Boer, e. a., ed., Wï Florens... De Hollandse graaf Floris $V$ in de samenleving van de dertiende eeuw (Utrecht, 1996) 154-172, in het bijzonder 164-166. 
nog hogere mate afhankelijk van de grafelijke gunst. De graaf kon dus zich verzekerd achten van hun trouw en toewijding. En juist dat gebrek aan een eigen machtsbasis van de nieuwe bestuursadel, hun afhankelijkheid van de graaf, maakte het mogelijk dat die groep genegeerd kon worden in de Rijmkroniek, de officiële Hollandse geschiedschrijving. Op die manier verwoordde Stoke de jegens de adel gevoerde politiek van zijn opdrachtgevers, Jan II en Willem III, en zette hij zowel de oude als de nieuwe adel op hun plaats. De oude garde werd ingepeperd dat zij verantwoordelijk waren voor alle problemen van het recente verleden, en dat om die reden hun rol voorlopig was uitgespeeld. De nieuwe lichting werd een lesje in nederigheid geleerd; zij waren weliswaar invloedrijk, maar slechts dankzij hun meester, de graaf. Hun macht was een afgeleide van de grafelijke macht, en slechts door onvoorwaardelijke trouw mochten zij hopen hun posities te behouden.

Deze adelspolitiek van de Henegouwse graven, hoewel uit nood geboren, heeft ongetwijfeld zijn vruchten afgeworpen. Tijdens de lange regering van Willem III, later niet voor niets geëerd met de bijnaam 'de Goede', heersten rust en vrede in het graafschap. Willem slaagde erin een verzoening met zijn tegenstanders te realiseren, waarmee enkele leden van de oude adelsgeslachten, zoals Jan van Arkel, Dirk van Brederode en burggraaf Hendrik van Leiden, weer een plaats in het landsbestuur kregen $^{71}$. Daar konden zij evenwel de intussen machtig geworden jonge geslachten niet uit hun vooraanstaande posities verdringen. Deze laatsten dienden de graaf loyaal, wat hun overigens geen windeieren legde. Dat die toestand niet kon voortduren, bewezen later de Hoekse en Kabeljauwse twisten. De nieuwe adel was toen zelf zo vermogend en invloedrijk geworden, dat zij bij de troebelen van 1350-1354 op hun beurt een eigen machtspolitiek konden gaan bedrijven, met de bekende kwalijke gevolgen voor het land. Voor het zover was, was echter kostbare tijd gewonnen. Graaf Willem III kon zonder problemen een groot deel van zijn tijd en energie wijden aan het bestuur van zijn stamland Henegouwen en aan zijn voorname rol in de internationale politiek. Dat de inwoners van Holland en Zeeland hem voor dat laatste de financiële middelen konden verschaffen, bewijst dat zij deze periode van rust hebben gebruikt om hun welvaart uit te breiden. De economische groei, met name van handel en nijverheid in de grote en kleine steden, die begon in de dertiende eeuw, kon in de eerste helft van de veertiende eeuw sterk worden uitgebouwd. Ongetwijfeld is de eerste aanzet voor Hollands latere voorsprong gegeven in deze periode van welvaart. De voorwaarden daartoe - rust en stabiliteit - zijn mede geschapen door de tijdelijke pacificering van de in andere tijden zo oproerige adel. Het is die neutralisering van de adel die we weerspiegeld zien in Stokes Rijmkroniek.

71 Zie Smit, ' Begin regeering Henegouwsche graven', 33. 


\section{Nederlandse katholieken in een overgangstijdperk: omslag en terug- slag in de jaren $1780-1830 *$}

\section{J. P. DE VALK}

Op 5 augustus 1796 decreteerde de Nationale Vergadering van de Bataafse Republiek (zonder te wachten op het gereedkomen van het Plan van Constitutie uit hetzelfde jaar) dat er geen 'heersende kerk' meer kon of zou worden geduld en dat alle wetgeving en beschikkingen daarmee samenhangend als vernietigd werden beschouwd. 1. Daarmee kwam formeel een einde aan een religieus systeem dat in ruim twee eeuwen was gegroeid. Onder het nieuwe regime mocht de maatschappelijke orde niet langer mede door godsdienstig verschil worden bepaald. Ook de nieuwe machthebbers achtten de godsdienst van fundamenteel belang voor de staat, maar het belijden daarvan was een zaak van de individuele burger geworden. De kerkgenootschappen schoven van de openbare naar de privé-sfeer. Het Plan van Constitutie, vaak nog al wijdlopig, weet dat in enkele artikelen kernachtig te formuleren: de religie is 'de eenige bron van eeuwig Heil' en de 'grondslag van Deugd, van goede Zeeden, en daar van onafscheidelijk Volks-geluk' (art. 704); de kerk wordt 'afgescheiden van den Staat, er zyn dus geene Burgerlijke voor- of na-deelen aan de Belydenis van eenige Godsdienstige begrippen gehegt' (art. 706); alle kerkgenootschappen staan 'onder gelyke bescherming der Wet' (art. 707). En tenslotte, niet minder belangrijk: buiten de kerkgebouwen mag niemand verschijnen 'met eenige ordenkleederen van eenig Godsdienstig Genootschap' (art 710) ${ }^{2}$. Men wilde ook de zichtbaarheid van het verschil uitbannen. In de opeenvolgende Nederlandse constituties en grondwetten tot en met die van 1815 is het hoofdmoment uit deze artikelen gehandhaafd: het afwijzen van maatschappelijk onderscheid tussen de staatsburgers op grond van hun geloofsovertuiging en het daaruit voortvloeiende behoren tot een kerkgenootschap. Voor het uitgangspunt van de scheiding tussen kerk en staat geldt dat veel minder. De concrete scheiding tussen de kerkgenootschappen en de staat bleek in de praktijk wat meer problemen op te leveren. De staat deed niet graag afstand van de mogelijkheden tot beïnvloeding van de burgers die kerk en godsdienst boden $^{3}$. In 1801 werd de positie van de voormalige publieke kerk weer wat verstevigd, sinds 1809 werd het toezicht op de kerkgenootschappen toevertrouwd aan een departement van Eredienst.Tijdens de aanhechting bij Frankrijk (1810-1813) en de periode van het Verenigd Koninkrijk zou de overheidsbemoeienis er niet minder op worden.

Hoewel herdenken sinds de negentiende eeuw erg populair is, hebben voorzover ik

\footnotetext{
* De geannoteerde en enigszins bewerkte tekst van een voordracht uitgesproken op 24 oktober 1996 tijdens het KNHG-congres over het ontstaan van het moderne Nederland, 1780-1830.

1 Tekst bij J. Th. de Visser, Kerk en Slaat, III (Leiden, 1927) 21 -23.

2 Plan van Constitutie voor het Volk van Nederland... (Den Haag, 1796) 109-110; als facsimile opgenomen in appendice bij L. de Gou, ed., Het Plan van Constitutie van 1796 (Den Haag, 1975).

3 Zie J. A. Bornewasser, 'The authority of the Dutch State over the Churches, 1795-1853', in: A. C. Duke en C. A. Tamse, ed., Church and State since the Reformation (Den Haag, 1981) 158-166.
} 